\title{
Synthesis, structure and redox properties of some thiosemicarbazone complexes of rhodium
}

\author{
Swati Dutta, ${ }^{a}$ Falguni Basuli, ${ }^{a}$ Shie-Ming Peng, ${ }^{b}$ Gene-Hsiang Lee ${ }^{b}$ and \\ Samaresh Bhattacharya ${ }^{* a}$ \\ ${ }^{a}$ Department of Chemistry, Inorganic Chemistry Section, Jadavpur University, \\ Kolkata 700032, India. E-mail: samaresh_b@hotmail.com \\ ${ }^{b}$ Department of Chemistry, National Taiwan University, Taipei, Taiwan, ROC
}

Received (in Montpellier, France) 31st May 2002, Accepted 19th July 2002

First published as an Advance Article on the web 25th September 2002

Reaction of salicylaldehyde thiosemicarbazone $\left(\mathrm{H}_{2} \mathrm{~L}^{1}\right)$, 2-hydroxyacetophenone thiosemicarbazone $\left(\mathrm{H}_{2} \mathrm{~L}^{2}\right)$ and 2-hydroxynaphthaldehyde thiosemicarbazone $\left(\mathrm{H}_{2} \mathrm{~L}^{3}\right)$ (general abbreviation $\mathrm{H}_{2} \mathrm{~L}$, where $\mathrm{H}_{2}$ stands for the two dissociable protons, one phenolic proton and one hydrazinic proton) with $\left[\mathrm{Rh}\left(\mathrm{PPh}_{3}\right)_{3} \mathrm{Cl}\right]$ afforded a family of rhodium(III) complexes of the type $\left[\mathrm{Rh}\left(\mathrm{PPh}_{3}\right)_{2}(\mathrm{~L}) \mathrm{Cl}\right]$. The crystal structure of $\left[\mathrm{Rh}\left(\mathrm{PPh}_{3}\right)_{2}\left(\mathrm{~L}^{2}\right) \mathrm{Cl}\right]$ has been determined by X-ray diffraction. The thiosemicarbazone ligands are coordinated, via dissociation of the two protons, as dianionic tridentate $\mathrm{O}, \mathrm{N}, \mathrm{S}$-donor ligands forming one six-membered and one five-membered chelate rings. The complexes are diamagnetic (low-spin $\mathrm{d}^{6}, S=0$ ) and their ${ }^{1} \mathrm{H}$ NMR spectra are in excellent agreement with their compositions. All three $\left[\mathrm{Rh}\left(\mathrm{PPh}_{3}\right)_{2}(\mathrm{~L}) \mathrm{Cl}\right]$ complexes display intense absorptions in the visible and ultraviolet regions. They also show strong emission in the visible region at ambient temperature. Cyclic voltammetry on all the complexes shows two irreversible oxidations, the first one is observed within 0.77 to $0.85 \mathrm{~V}$ vs. SCE and the second one within 1.13 to $1.23 \mathrm{~V}$ vs. SCE, and one irreversible reduction within -1.05 to $-1.14 \mathrm{~V}$ vs. SCE.

There has been considerable interest in the chemistry of transition metal complexes of thiosemicarbazone ligands, primarily because of their bioinorganic relevance. ${ }^{1}$ This class of complexes is of particular importance because of the potentially beneficial biological (viz. antibacterial, antimalarial, antiviral and antitumor) activities of these compounds. ${ }^{2}$ Thiosemicarbazones usually bind to a metal ion as bidentate $\mathrm{N}$,S-donor ligands via dissociation of the hydrazinic proton, forming five-membered chelate rings (1). ${ }^{3}$ When a third donor site (D) is incorporated into the ligands, linked to the carbonylic carbon via one or two intervening atoms, normally D,N,S-tricoordination (2) takes place. ${ }^{4}$ Examples are also known where such ligands, in addition to displaying $\mathrm{D}, \mathrm{N}, \mathrm{S}$-tricoordination, bridge a second metal ion through the sulfur. ${ }^{5}$ However, we have observed that in its reaction with $\left[\mathrm{M}\left(\mathrm{PPh}_{3}\right)_{3} \mathrm{X}_{2}\right](\mathrm{M}=\mathrm{Ru}, \mathrm{Os} ; \mathrm{X}=\mathrm{Cl}, \mathrm{Br})$ salicylaldehyde thiosemicarbazone, in spite of having the phenolic oxygen as a potential third donor site, coordinates as a bidentate N,S-donor forming a rather unusual four-membered chelate ring (3). ${ }^{6}$ Some other thiosemicarbazone ligands are also known to display a similar coordination mode. ${ }^{7}$ Though formation of such a chelate ring (3) by salicylaldehyde thiosemicarbazone, leaving some potential donor sites unused, has been successfully utilized in the construction of polynuclear complexes, ${ }^{8}$ this unusual coordination mode has encouraged us to search for suitable synthetic conditions so that the expected normal O,N,S-tricoordination (4) from the same salicylaldehyde thiosemicarbazone ligand may take place.
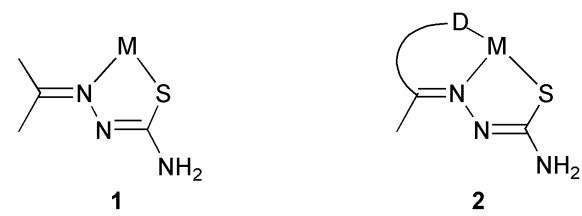

2
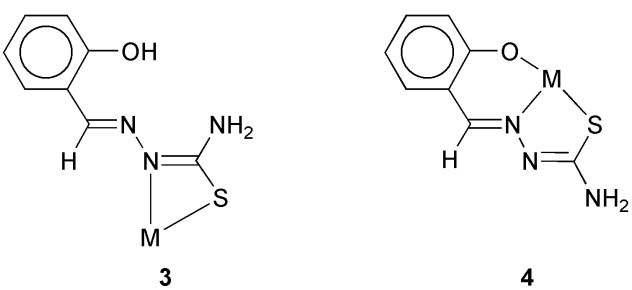

3

In the present work, which has originated from our interest in the different coordination modes of the thiosemicarbazone ligands in general, ${ }^{3-9}$ and to induce coordination mode $\mathbf{4}$ in particular, we have chosen the thiosemicarbazones of salicylaldehyde, 2-hydroxyacetophenone and 2-hydroxynaphthaldehyde as the ligands and rhodium as the metal. The thiosemicarbazone ligands are abbreviated in general as $\mathrm{H}_{2} \mathrm{~L}$, where $\mathrm{H}_{2}$ stands for the two dissociable protons, the phenolic proton and the hydrazinic proton. Individual ligand abbreviations are shown in $\mathbf{5}$. It may be mentioned here that chemistry of the thiosemicarbazone complexes of rhodium appears to remain unexplored. As the rhodium starting material, we have chosen Wilkinson's catalyst, viz. [ $\left.\mathrm{Rh}\left(\mathrm{PPh}_{3}\right)_{3} \mathrm{Cl}\right]$, because it is known to undergo dissociation in solution, producing free $\mathrm{PPh}_{3}$ and a formally tricoordinated $\mathrm{Rh}\left(\mathrm{PPh}_{3}\right)_{2} \mathrm{Cl}$ species, ${ }^{10}$ 
which has been observed by us to serve as an useful synthon for the preparation of interesting complexes, ${ }^{11}$ furthermore, this tricoordinated species appears suitable for the desired $\mathrm{O}, \mathrm{N}, \mathrm{S}$-tricoordination of the thiosemicarbazone ligands. This strategy has indeed worked nicely, affording a group of rhodium complexes of type $\left[\mathrm{Rh}\left(\mathrm{PPh}_{3}\right)_{2}(\mathrm{~L}) \mathrm{Cl}\right]$ containing the thiosemicarbazone ligands coordinated in the tridentate fashion (4). The chemistry of these complexes is reported in this paper with special reference to synthesis, structure and electrochemical properties.
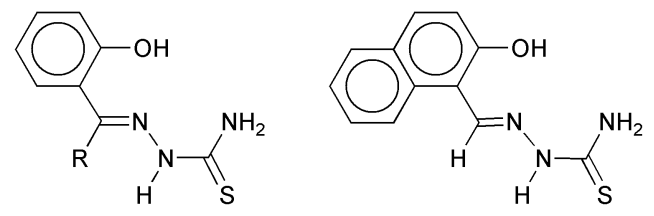

$\mathrm{H}_{2} \mathrm{~L}^{1}(\mathrm{R}=\mathrm{H})$

$\mathrm{H}_{2} \mathrm{~L}^{2}\left(\mathrm{R}=\mathrm{CH}_{3}\right)$
$\mathrm{H}_{2} \mathrm{~L}^{3}$
5

\section{Experimental}

\section{Materials and physical measurements}

Rhodium trichloride was obtained from Arora Matthey, Kolkata, India and triphenylphosphine was purchased from Loba Chemie, Mumbai, India. $\left[\mathrm{Rh}\left(\mathrm{PPh}_{3}\right)_{3} \mathrm{Cl}\right]$ was synthesized following a reported procedure. ${ }^{12}$ The thiosemicarbazone ligands were prepared by condensing the respective aldehyde or ketone with thiosemicarbazide. Purification of dichloromethane and preparation of tetrabutylammonium perchlorate (TBAP) for electrochemical work were performed as before. ${ }^{13}$

Microanalyses $(\mathrm{C}, \mathrm{H}, \mathrm{N})$ were performed using a Heraeus Carlo Erba 1108 elemental analyzer. IR spectra were obtained on a Shimadzu FTIR-8300 spectrometer with samples prepared as $\mathrm{KBr}$ pellets. Electronic spectra were recorded on a JASCO V-570 spectrophotometer. Emission spectra were recorded on a Spex Fluorolog spectrometer. Magnetic susceptibilities were measured using a PAR 155 vibrating sample magnetometer fitted with a Walker Scientific L75FBAL magnet. ${ }^{1} \mathrm{H}$ NMR spectra were recorded in $\mathrm{CDCl}_{3}$ solution with a Brucker drx 500 NMR spectrometer using TMS as the internal standard. Electrochemical measurements were done in $1: 9$ dichloromethane-acetonitrile solution (0.1 M TBAP), using a $\mathrm{CH}$ Instruments model 600A electrochemical analyzer. The addition of $10 \%$ dichloromethane was necessary to dissolve the complexes while the acetonitrile was necessary for the detection of the rhodium(III)-rhodium(II) reductive response. A platinum disc working electrode, a platinum wire auxiliary electrode and an aqueous saturated calomel reference electrode (SCE) were used in a three-electrode configuration. Electrochemical measurements were made under a dinitrogen atmosphere. All electrochemical data were collected at $298 \mathrm{~K}$ and are uncorrected for junction potentials.

\section{Synthetic procedures}

[Rh( $\left.\left.\mathbf{P P h} \mathbf{h}_{\mathbf{2}}\right)_{\mathbf{2}}\left(\mathbf{L}^{\mathbf{1}}\right) \mathbf{C l}\right] . \mathrm{H}_{2} \mathbf{L}^{1}(21 \mathrm{mg}, 0.11 \mathrm{mmol})$ was dissolved in benzene and to it were added triethylamine $(22 \mathrm{mg}$, $0.22 \mathrm{mmol})$ and $\left[\mathrm{Rh}\left(\mathrm{PPh}_{3}\right)_{3} \mathrm{Cl}\right](100 \mathrm{mg}, 0.11 \mathrm{mmol})$. The mixture was then heated at reflux under a dinitrogen atmosphere for $12 \mathrm{~h}$ to afford an orange solution. Evaporation of this solution gave an orangish-yellow solid, which was subjected to purification by thin layer chromatography on a silica plate. With benzene-acetonitrile $(3: 1)$ as the eluant, an orange band separated, which was extracted with acetonitrile. Upon evaporation of the acetonitrile extract $\left[\mathrm{Rh}\left(\mathrm{PPh}_{3}\right)_{2}\left(\mathrm{~L}^{1}\right) \mathrm{Cl}\right]$ was obtained as a crystalline orange solid. Yield: $75 \%$. Calcd: C, 61.72; H, 4.33; N, 4.91. Found: C, 61.05; H, 4.37; N, 4.97\%.

$\left[\mathbf{R h}\left(\mathbf{P P h}_{\mathbf{3}}\right)_{\mathbf{2}}\left(\mathbf{L}^{\mathbf{2}}\right) \mathbf{C l ]}\right.$. This complex was prepared by following the same procedure as above, using $\mathrm{H}_{2} \mathrm{~L}^{2}$ instead of $\mathrm{H}_{2} \mathrm{~L}^{1}$. Yield: 70\%. Calcd: C, 62.11; H, 4.49; N, 4.83. Found: C, $61.65 ; \mathrm{H} 4.42 ; \mathrm{N}, 4.88 \%$.

$\left[\mathbf{R h}\left(\mathbf{P P h}_{\mathbf{3}}\right)_{\mathbf{2}}\left(\mathbf{L}^{\mathbf{3}}\right) \mathbf{C l}\right]$. This complex was prepared by following the same procedure as for $\left[\mathrm{Rh}\left(\mathrm{PPh}_{3}\right)_{2}\left(\mathrm{~L}^{1}\right) \mathrm{Cl}\right]$, using $\mathrm{H}_{2} \mathrm{~L}^{3}$ instead of $\mathrm{H}_{2} \mathrm{~L}^{1}$. Yield: $72 \%$. Calcd: $\mathrm{C}, 63.62 ; \mathrm{H}, 4.31 ; \mathrm{N}$, 4.64. Found: C, 63.27; H, 4.52; N, 4.70\%.

\section{X-Ray crystallography}

Single crystals of $\left[\mathrm{Rh}\left(\mathrm{PPh}_{3}\right)_{2}\left(\mathrm{~L}^{2}\right) \mathrm{Cl}\right]$ were grown by slow diffusion of hexane into a dichloromethane solution of the complex. Selected crystal data and data collection parameters are given in Table 1. Data were collected on an Enraf-Nonius CAD4 diffractometer using graphite monochromated $\mathrm{MoK} \alpha$ radiation $(\lambda=0.71073 \AA)$ by $\omega-2 \theta$ scans. The data were corrected for empirical absorption on the basis of psi scans. X-Ray structure solution and refinement were done using the SHELXS-97 and SHELXL-97 programs. ${ }^{14}$ Hydrogen atoms were fixed at calculated positions and were refined using a riding mode. The structure was solved by direct methods.

CCDC reference number 192601. See http://www.rsc.org/ suppdata/nj/b2/b205338c/ for crystallographic files in CIF or other electronic format.

\section{Results and discussion}

Reaction of the thiosemicarbazone ligands $\mathrm{H}_{2} \mathrm{~L}$ with $\left[\mathrm{Rh}\left(\mathrm{PPh}_{3}\right)_{3} \mathrm{Cl}\right]$ proceeds smoothly in refluxing benzene in the presence of triethylamine to afford the $\left[\mathrm{Rh}\left(\mathrm{PPh}_{3}\right)_{2}(\mathrm{~L}) \mathrm{Cl}\right]$ complexes in decent yields. Elemental $(\mathrm{C}, \mathrm{H}, \mathrm{N})$ analytical data of the complexes are consistent with their compositions. It is interesting to note that rhodium has undergone a two-electron oxidation during the course of the synthetic reaction and the trace of oxygen, present in the reaction vessel, might have served as the oxidizing agent. It appears from the formulation of these complexes that the thiosemicarbazone ligands are serving as tridentate ligands. To find out the coordination mode of the thiosemicarbazone ligands and the stereochemistry of the complexes, the structure of one member of this family, viz. $\left[\mathrm{Rh}\left(\mathrm{PPh}_{3}\right)_{2}\left(\mathrm{~L}^{2}\right) \mathrm{Cl}\right]$, has been determined by $\mathrm{X}$-ray crystallography. A view of the complex molecule is shown in Fig. 1 and selected bond parameters are listed in Table 2. The thiosemicarbazone ligand $\left(\mathrm{L}^{2}\right)$ is coordinated to rhodium in the

Table 1 Crystallographic data of $\left[\mathrm{Rh}\left(\mathrm{PPh}_{3}\right)_{2}\left(\mathrm{~L}^{2}\right) \mathrm{Cl}\right]$

\begin{tabular}{ll}
\hline Formula & $\mathrm{C}_{45} \mathrm{H}_{39} \mathrm{ClN}_{3} \mathrm{OP}_{2} \mathrm{SRh}$ \\
Formula weight & 870.15 \\
Crystal system & Monoclinic \\
Space group & $P 2{ }_{1} / c$ \\
$a / \AA$ & $23.236(3)$ \\
$b / \AA$ & $17.497(4)$ \\
$c / \AA$ & $19.446(3)$ \\
$\beta /$ deg & $90.055(13)$ \\
$U / \AA^{3}$ & $7906(3)$ \\
$Z$ & 8 \\
$T / \mathrm{K}$ & 295 \\
$\mu / \mathrm{mm}$ & -1 \\
$\mathrm{Reflections} \mathrm{collected}$ & 0.763 \\
Independent reflections & 13917 \\
$R_{\text {int }}$ & 13917 \\
$R_{1}$ & 0.00 \\
$w R_{2}$ & 0.0429 \\
\hline
\end{tabular}




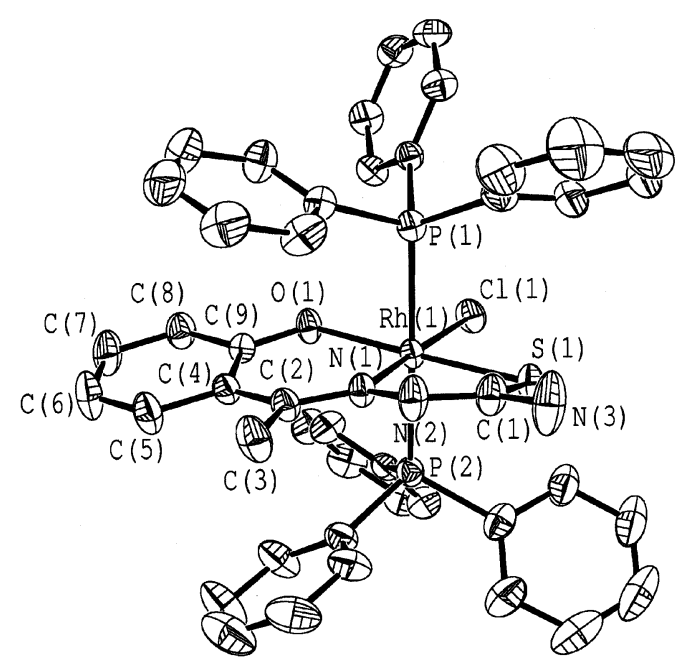

Fig. 1 View of the $\left[\mathrm{Rh}\left(\mathrm{PPh}_{3}\right)_{2}\left(\mathrm{~L}^{2}\right) \mathrm{Cl}\right]$ molecule.

tridentate fashion (4), forming five- and six-membered chelate rings with bite angles of $\sim 85^{\circ}(\mathrm{N}-\mathrm{Rh}-\mathrm{S})$ and $\sim 93^{\circ}(\mathrm{O}-\mathrm{Rh}-\mathrm{N})$, respectively. The thiosemicarbazone ligand, the coordinated chloride ion and rhodium constitute the pseudo-equatorial plane and the two triphenylphosphine ligands are mutually trans. The $\mathrm{ONSP}_{2} \mathrm{ClRh}$ core is a distorted octahedron, as reflected in all the bond parameters around rhodium. The $\mathrm{Rh}-\mathrm{Cl}$ and $\mathrm{Rh}-\mathrm{P}$ lengths are quite normal and so are the $\mathrm{Rh}-\mathrm{N}, \mathrm{Rh}-\mathrm{O}$ and $\mathrm{Rh}-\mathrm{S}$ distances. ${ }^{11,15}$ Comparison of the bond lengths in the coordinated thiosemicarbazone $\left(\mathrm{L}^{2}\right)$ ligand with those in the free thiosemicarbazone $\left(\mathrm{H}_{2} \mathrm{~L}^{2}\right)$ ligand $^{16}$ shows that, upon coordination, the $\mathrm{C}-\mathrm{S}$ bond has elongated while the adjacent $\mathrm{C}-\mathrm{N}$ bond has contracted. These changes in bond lengths are attributable to stabilization of the

Table 2 Selected bond parameters (distances in $\AA$, angles in ${ }^{\circ}$ ) for $\left[\mathrm{Rh}\left(\mathrm{PPh}_{3}\right)_{2}\left(\mathrm{~L}^{2}\right) \mathrm{Cl}\right]$

\begin{tabular}{|c|c|c|c|}
\hline \multicolumn{2}{|l|}{ Molecule 1} & \multicolumn{2}{|l|}{ Molecule 2} \\
\hline $\mathrm{Rh}(1)-\mathrm{N}(1)$ & $2.012(3)$ & $\mathrm{Rh}(2)-\mathrm{N}(4)$ & $2.013(3)$ \\
\hline $\mathrm{Rh}(1)-\mathrm{O}(1)$ & $2.035(3)$ & $\mathrm{Rh}(2)-\mathrm{O}(2)$ & $2.026(3)$ \\
\hline $\mathrm{Rh}(1)-\mathrm{P}(1)$ & $2.3920(12)$ & $\mathrm{Rh}(2)-\mathrm{P}(3)$ & $2.3889(12)$ \\
\hline $\mathrm{Rh}(1)-\mathrm{P}(2)$ & $2.3929(12)$ & $\mathrm{Rh}(2)-\mathrm{P}(4)$ & $2.4003(12)$ \\
\hline $\operatorname{Rh}(1)-S(1)$ & $2.2935(12)$ & $\mathrm{Rh}(2)-\mathrm{S}(2)$ & $2.3030(13)$ \\
\hline $\mathrm{Rh}(1)-\mathrm{Cl}(1)$ & $2.3634(10)$ & $\mathrm{Rh}(2)-\mathrm{Cl}(2)$ & $2.3561(11)$ \\
\hline $\mathrm{C}(9)-\mathrm{O}(1)$ & $1.312(4)$ & $\mathrm{C}(54)-\mathrm{O}(2)$ & $1.313(5)$ \\
\hline $\mathrm{C}(2)-\mathrm{N}(1)$ & $1.299(4)$ & $\mathrm{C}(47)-\mathrm{N}(4)$ & $1.307(5)$ \\
\hline $\mathrm{N}(1)-\mathrm{N}(2)$ & $1.415(4)$ & $\mathrm{N}(4)-\mathrm{N}(5)$ & $1.402(5)$ \\
\hline $\mathrm{N}(2)-\mathrm{C}(1)$ & $1.298(5)$ & $\mathrm{N}(5)-\mathrm{C}(46)$ & $1.294(5)$ \\
\hline $\mathrm{C}(1)-\mathrm{S}(1)$ & $1.724(4)$ & $\mathrm{C}(46)-\mathrm{S}(2)$ & $1.710(5)$ \\
\hline $\mathrm{C}(1)-\mathrm{N}(3)$ & $1.369(5)$ & $\mathrm{C}(46)-\mathrm{N}(6)$ & $1.381(6)$ \\
\hline $\mathrm{O}(1)-\mathrm{Rh}(1)-\mathrm{S}(1)$ & $176.00(8)$ & $\mathrm{O}(2)-\mathrm{Rh}(2)-\mathrm{S}(2)$ & $177.15(8)$ \\
\hline $\mathrm{P}(1)-\mathrm{Rh}(1)-\mathrm{P}(2)$ & $174.83(4)$ & $\mathrm{P}(3)-\mathrm{Rh}(2)-\mathrm{P}(4)$ & $172.56(4)$ \\
\hline $\mathrm{N}(1)-\mathrm{Rh}(1)-\mathrm{Cl}(1)$ & 177.27(9) & $\mathrm{N}(4)-\mathrm{Rh}(2)-\mathrm{Cl}(2)$ & $178.27(10)$ \\
\hline $\mathrm{N}(1)-\mathrm{Rh}(1)-\mathrm{O}(1)$ & $92.63(11)$ & $\mathrm{N}(4)-\mathrm{Rh}(2)-\mathrm{O}(2)$ & $92.34(12)$ \\
\hline $\mathrm{S}(1)-\mathrm{Rh}(1)-\mathrm{P}(1)$ & $92.99(4)$ & $\mathrm{S}(2)-\mathrm{Rh}(2)-\mathrm{P}(3)$ & $92.87(4)$ \\
\hline $\mathrm{S}(1)-\mathrm{Rh}(1)-\mathrm{P}(2)$ & $90.35(4)$ & $\mathrm{S}(2)-\mathrm{Rh}(2)-\mathrm{P}(4)$ & $90.78(4)$ \\
\hline $\mathrm{S}(1)-\mathrm{Rh}(1)-\mathrm{Cl}(1)$ & $92.79(4)$ & $\mathrm{S}(2)-\mathrm{Rh}(2)-\mathrm{Cl}(2)$ & $93.50(4)$ \\
\hline $\mathrm{N}(1)-\mathrm{Rh}(1)-\mathrm{P}(1)$ & $89.62(10)$ & $\mathrm{N}(4)-\mathrm{Rh}(2)-\mathrm{P}(3)$ & $92.85(10)$ \\
\hline $\mathrm{Cl}(1)-\mathrm{Rh}(1)-\mathrm{P}(1)$ & $90.73(4)$ & $\mathrm{Cl}(2)-\mathrm{Rh}(2)-\mathrm{P}(3)$ & $86.86(4)$ \\
\hline $\mathrm{O}(1)-\mathrm{Rh}(1)-\mathrm{Cl}(1)$ & $90.09(8)$ & $\mathrm{O}(2)-\mathrm{Rh}(2)-\mathrm{Cl}(2)$ & $89.35(8)$ \\
\hline $\mathrm{N}(1)-\mathrm{Rh}(1)-\mathrm{P}(2)$ & $94.63(10)$ & $\mathrm{N}(4)-\mathrm{Rh}(2)-\mathrm{P}(4)$ & $93.94(10)$ \\
\hline $\mathrm{N}(1)-\mathrm{Rh}(1)-\mathrm{S}(1)$ & $84.49(9)$ & $\mathrm{N}(4)-\mathrm{Rh}(2)-\mathrm{S}(2)$ & $84.81(10)$ \\
\hline $\mathrm{O}(1)-\mathrm{Rh}(1)-\mathrm{P}(1)$ & $84.21(8)$ & $\mathrm{O}(2)-\mathrm{Rh}(2)-\mathrm{P}(3)$ & $87.23(9)$ \\
\hline $\mathrm{O}(1)-\mathrm{Rh}(1)-\mathrm{P}(2)$ & $92.65(8)$ & $\mathrm{O}(2)-\mathrm{Rh}(2)-\mathrm{P}(4)$ & $89.45(9)$ \\
\hline $\mathrm{Cl}(1)-\mathrm{Rh}(1)-\mathrm{P}(2)$ & $85.16(4)$ & $\mathrm{Cl}(2)-\mathrm{Rh}(2)-\mathrm{P}(4)$ & $86.45(4)$ \\
\hline $\mathrm{Rh}(1)-\mathrm{S}(1)-\mathrm{C}(1)$ & $94.37(14)$ & $\mathrm{Rh}(2)-\mathrm{S}(2)-\mathrm{C}(46)$ & $94.43(16)$ \\
\hline
\end{tabular}

iminothiolate form of the thiosemicarbazone ligand upon complexation via loss of the hydrazinic proton. The phenolic $\mathrm{C}-\mathrm{O}$ length has also decreased upon coordination. Similar structural features are known for other metal complexes of such ligands that have O,N,S coordination. ${ }^{4 d-g, 17}$ As all three complexes display similar spectral and electrochemical properties (vide infra), the other two complexes are assumed to have the same structure as $\left[\mathrm{Rh}\left(\mathrm{PPh}_{3}\right)_{2}\left(\mathrm{~L}^{2}\right) \mathrm{Cl}\right]$.

The difference in coordination mode displayed by the salicylaldehyde thiosemicarbazone ligand (and similar ligands) in their reaction with $\left[\mathrm{Ru}\left(\mathrm{PPh}_{3}\right)_{3} \mathrm{Cl}_{2}\right]\left(\right.$ mode 3) and $\left[\mathrm{Rh}\left(\mathrm{PPh}_{3}\right)_{3} \mathrm{Cl}\right]$ (mode 4) is really interesting and hence deserves careful scrutiny. The reason is probably kinetic in nature, which has been illustrated in Scheme 1. [Ru( $\left.\left(\mathrm{PPh}_{3}\right)_{3} \mathrm{Cl}_{2}\right]$ is known to undergo dissociation upon dissolution, affording free $\mathrm{PPh}_{3}$ and a formally tetracoordinated $\left[\mathrm{Ru}\left(\mathrm{PPh}_{3}\right)_{2} \mathrm{Cl}_{2}\right]$ species. ${ }^{18}$ Formation of the bis thiosemicarbazone complex (6) from this reactive $\left[\mathrm{Ru}\left(\mathrm{PPh}_{3}\right)_{2} \mathrm{Cl}_{2}\right]$ species therefore involves chelation of the two thiosemicarbazone ligands via breaking of two $\mathrm{Ru}-\mathrm{Cl}$ bonds (reaction 1). $\left[\mathrm{Rh}\left(\mathrm{PPh}_{3}\right)_{3} \mathrm{Cl}\right]$ also dissociates in solution into $\mathrm{PPh}_{3}$ and a formally tricoordinated $\left[\mathrm{Rh}\left(\mathrm{PPh}_{3}\right)_{2} \mathrm{Cl}\right]$ species. ${ }^{10}$ However, formation of the $\left[\mathrm{Rh}\left(\mathrm{PPh}_{3}\right)_{2}\left(\mathrm{~L}^{1}\right) \mathrm{Cl}\right]$ complex (7) from the tricoordinated $\left[\mathrm{Rh}\left(\mathrm{PPh}_{3}\right)_{2} \mathrm{Cl}\right]$ species involves only chelation by the thiosemicarbazone ligand without breaking any pre-existing Rh-ligand bond (reaction 2). Hence coordination of salicyladehyde thiosemicarbazone in the tridentate fashion appears to have taken place without any difficulty in the case of rhodium (reaction 2). Formation of such an $\mathrm{O}, \mathrm{N}, \mathrm{S}$-chelate (as in 7) has not been possible in the ruthenium case (reaction 1) probably because three coordination positions were not available on ruthenium in the reactive $\left[\mathrm{Ru}\left(\mathrm{PPh}_{3}\right)_{2} \mathrm{Cl}_{2}\right]$ intermediate. In reaction 1 , formation of four-membered chelate rings and cleavage of $\mathrm{Ru}-\mathrm{Cl}$ bonds probably take place synergistically.

Magnetic susceptibility measurements show that the $\left[\mathrm{Rh}\left(\mathrm{PPh}_{3}\right)_{2}(\mathrm{~L}) \mathrm{Cl}\right]$ complexes are diamagnetic, which is in accordance with the trivalent state of rhodium (low-spin $\mathrm{d}^{6}$,

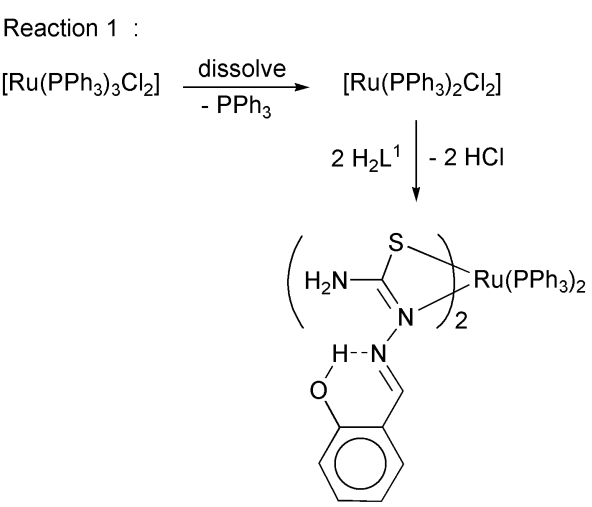

(6)

Reaction 2 :

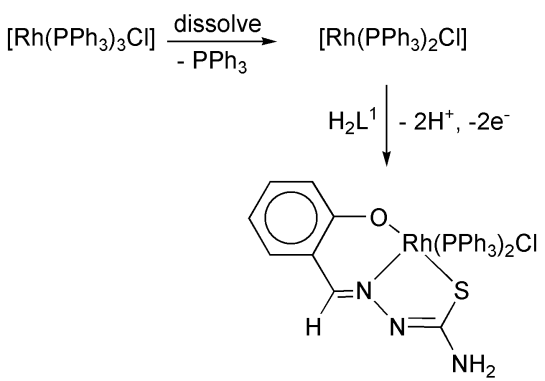

(7)

Scheme 1 


\begin{tabular}{|c|c|c|c|c|}
\hline \multirow[b]{3}{*}{ Compound } & \multirow[b]{3}{*}{ Absorption data ${ }^{a} \lambda_{\max } / \mathrm{nm}\left(\varepsilon / \mathrm{M}^{-1} \mathrm{~cm}^{-1}\right)$} & \multicolumn{3}{|c|}{ Emission data $^{b}$} \\
\hline & & \multicolumn{2}{|l|}{$\lambda_{\max } / \mathrm{nm}$} & \multirow[b]{2}{*}{ Quantum yield $(\phi)$} \\
\hline & & Excitation & Emission & \\
\hline$\left[\mathrm{Rh}\left(\mathrm{PPh}_{3}\right)_{2}\left(\mathrm{~L}^{1}\right) \mathrm{Cl}\right]$ & $428(8400), 340(16400), 300(30000), 260^{c}(42000)$ & 332 & 417 & $0.85 \times 10^{-3}$ \\
\hline$\left[\mathrm{Rh}\left(\mathrm{PPh}_{3}\right)_{2}\left(\mathrm{~L}^{2}\right) \mathrm{Cl}\right]$ & $406^{c}(8200), 332(21200), 278^{c}(39500)$ & 316 & 421 & $2.01 \times 10^{-3}$ \\
\hline$\left[\mathrm{Rh}\left(\mathrm{PPh}_{3}\right)_{2}\left(\mathrm{~L}^{3}\right) \mathrm{Cl}\right]$ & $464(4500), 442(4500), 346^{c}(8600), 304^{c}(16200), 272(23400)$ & 324 & 425 & $1.63 \times 10^{-3}$ \\
\hline
\end{tabular}

$S=0$ ) in these complexes. In the ${ }^{1} \mathrm{H}$ NMR spectra of all the complexes the $\mathrm{PPh}_{3}$ protons show broad signals within 7.1 to $7.8 \mathrm{ppm}$. In the $\left[\mathrm{Rh}\left(\mathrm{PPh}_{3}\right)_{2}\left(\mathrm{~L}^{1}\right) \mathrm{Cl}\right]$ complex, six signals were expected from the coordinated thiosemicarbazone ligand $\left(\mathrm{L}^{1}\right)$ and all of them have been distinctly observed [at 4.20 (singlet, $\mathrm{NH}_{2}$ ), 6.55 (singlet, azomethine proton), 6.16 (triplet), 6.28 (doublet), 6.68 (doublet) and 6.90 (triplet) ppm]. Similarly, in the $\left[\mathrm{Rh}\left(\mathrm{PPh}_{3}\right)_{2}\left(\mathrm{~L}^{2}\right) \mathrm{Cl}\right]$ complex, all the six expected signals from the coordinated thiosemicarbazone ligand $\left(\mathrm{L}^{2}\right)$ have been clearly observed [at 4.50 (singlet, $\mathrm{NH}_{2}$ ), 2.10 (singlet, $\mathrm{CH}_{3}$ ), 6.30 (quartet), 6.66 (doublet), 6.80 (triplet) and 6.85 (doublet) $\mathrm{ppm}]$. In the $\left[\mathrm{Rh}\left(\mathrm{PPh}_{3}\right)_{2}\left(\mathrm{~L}^{3}\right) \mathrm{Cl}\right]$ complex, eight signals were expected from the coordinated thiosemicarbazone ligand $\left(\mathrm{L}^{3}\right)$, of which seven have been observed [at 4.58 (singlet, $\mathrm{NH}_{2}$ ), 8.76 (singlet, azomethine proton), 7.00 (doublet), 7.03 (doublet), 7.12 (triplet), 7.74 (doublet) and 8.34 (singlet) ppm]. The last signal could not be detected because of overlap with the $\mathrm{PPh}_{3}$ signals. The ${ }^{1} \mathrm{H}$ NMR spectral data are therefore consistent with the compositions of the complexes.

Infrared spectra of the $\left[\mathrm{Rh}\left(\mathrm{PPh}_{3}\right)_{2}(\mathrm{~L}) \mathrm{Cl}\right]$ complexes show three strong bands near 520, 695 and $745 \mathrm{~cm}^{-1}$, which are attributable to the $\mathrm{Rh}\left(\mathrm{PPh}_{3}\right)_{2}$ fragment. ${ }^{11}$ Comparison with the spectrum of $\left[\mathrm{Rh}\left(\mathrm{PPh}_{3}\right)_{3} \mathrm{Cl}\right]$ shows the presence of some additional bands in the $\left[\mathrm{Rh}\left(\mathrm{PPh}_{3}\right)_{2}(\mathrm{~L}) \mathrm{Cl}\right]$ complexes (e.g., near $1620,1530,1435$ and $\left.1100 \mathrm{~cm}^{-1}\right)$, which must be due to the coordinated thiosemicarbazone ligand. The $\left[\mathrm{Rh}\left(\mathrm{PPh}_{3}\right)_{2}(\mathrm{~L}) \mathrm{Cl}\right]$ complexes are readily soluble in dichloromethane, chloroform, acetone, etc., producing intense yellow solutions. Electronic spectra of all the complexes have been recorded in dichloromethane solution. Spectral data are presented in Table 3 and a selected spectrum is shown in Fig. 2. Each complex shows

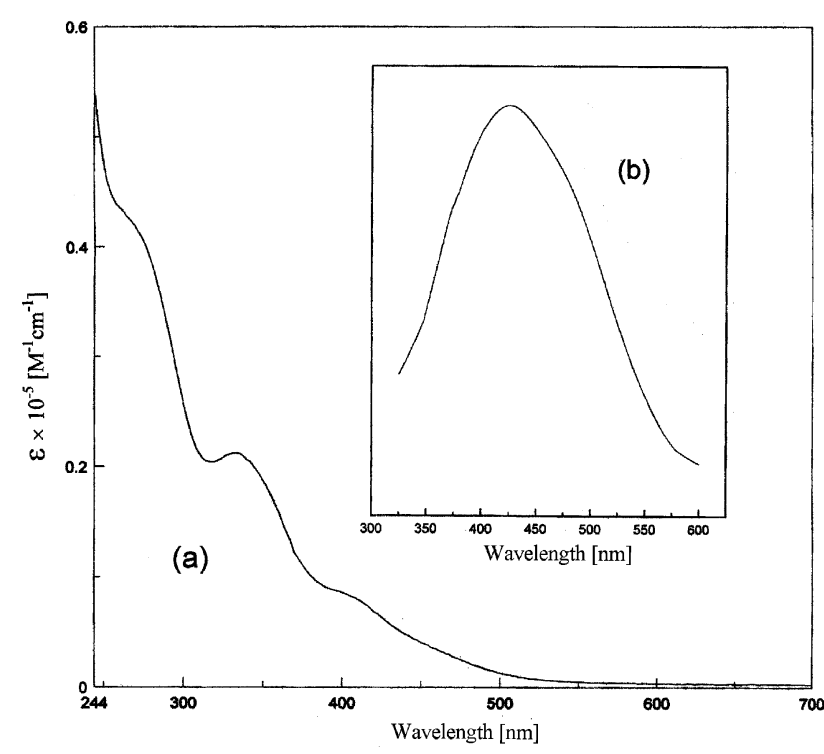

Fig. 2 (a) Absorption spectrum of $\left[\mathrm{Rh}\left(\mathrm{PPh}_{3}\right)_{2}\left(\mathrm{~L}^{2}\right) \mathrm{Cl}\right]$ in dichloromethane solution and (b) emission spectrum of $\left[\mathrm{Rh}\left(\mathrm{PPh}_{3}\right)_{2}\left(\mathrm{~L}^{2}\right) \mathrm{Cl}\right]$ in $1: 9$ dichloromethane-ethanol solution at $298 \mathrm{~K}\left(\lambda_{\mathrm{ex}}=316 \mathrm{~nm}\right)$. several intense absorptions in the visible and ultraviolet regions. The absorptions in the ultraviolet region are assignable to transitions within the ligand orbitals and those in the visible region are probably due to charge-transfer transitions involving both metal and ligand orbitals. For a better understanding of the nature of the transitions in the visible region, qualitative EHMO calculations have been performed ${ }^{19}$ on computer generated models of all three complex molecules in which the phenyl rings of the $\mathrm{PPh}_{3}$ ligands have been replaced by hydrogens. A partial MO diagram is displayed in Fig. 3 and the composition of some selected molecular orbitals is given in Table 4. The highest occupied molecular orbital (HOMO) and the next two filled orbitals (HOMO-1 and HOMO-2) have a major contribution from the $\mathrm{d}_{x y}, \mathrm{~d}_{y z}$ and $\mathrm{d}_{z x}$ orbitals of rhodium $^{20}$ and hence these three filled orbitals may be regarded as components of the metal $t_{2}$ orbitals. The lowest unoccupied molecular orbital (LUMO) and the next couple of vacant orbitals (e.g., LUMO +1 and $\mathrm{LUMO}+2$ ) are localized almost entirely on different parts of the thiosemicarbazone ligands. Hence the absorptions in the visible region may be assigned to charge-transfer transitions occurring from the filled $t_{2}$ orbitals of rhodium to the vacant $\pi^{*}$ orbitals of the thiosemicarbazone ligands. As metal-to-ligand charge-transfer transitions are relatively less common in complexes of rhodiu$\mathrm{m}(\mathrm{III})$, the observed charge-transfer transitions displayed by the $\left[\mathrm{Rh}\left(\mathrm{PPh}_{3}\right)_{2}(\mathrm{~L}) \mathrm{Cl}\right]$ complexes in the visible region have tempted us to explore the luminescence properties of these complexes. This has been carried out in $1: 9$ dichloromethane-ethanol solution at ambient temperature (298 K). All three complexes show strong emission in the visible region

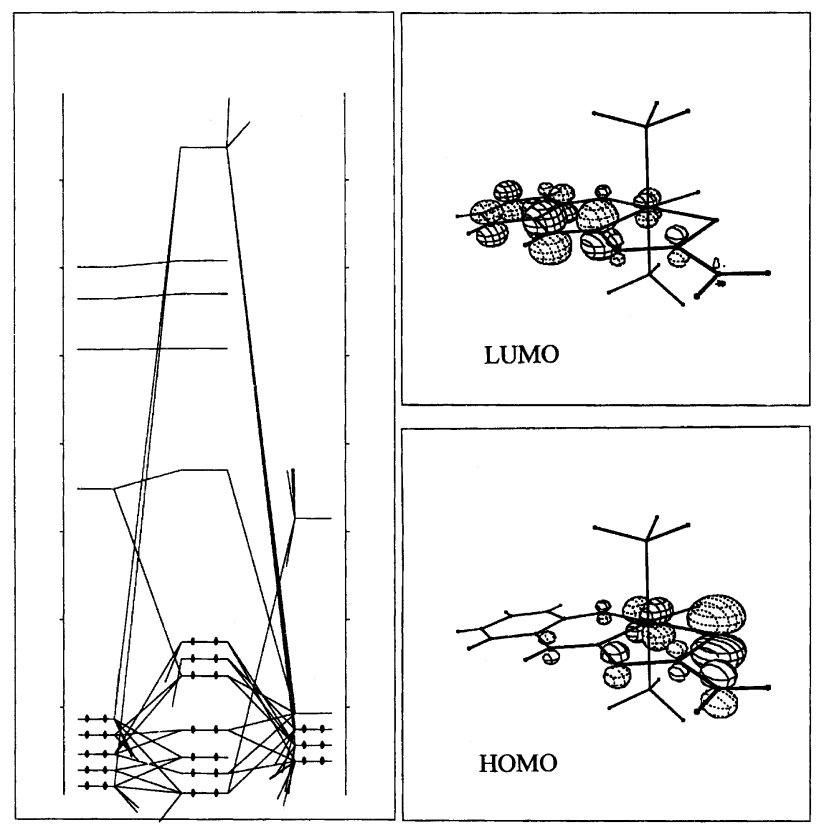

Fig. 3 Partial molecular orbital diagram of $\left[\mathrm{Rh}\left(\mathrm{PPh}_{3}\right)_{2}\left(\mathrm{~L}^{1}\right) \mathrm{Cl}\right]$. 
Table 4 Composition of selected molecular orbitals of the $\left.\left[\mathrm{Rh}\left(\mathrm{PPh}_{3}\right)_{2}(\mathrm{~L}) \mathrm{Cl}\right)\right]$ complexes

\begin{tabular}{llllllll}
\hline Compound & Contributing fragment & HOMO & HOMO-1 & HOMO-2 & LUMO & LUMO + & LUMO +2 \\
\hline$\left[\mathrm{Rh}\left(\mathrm{PPh}_{3}\right)_{2}\left(\mathrm{~L}^{1}\right) \mathrm{Cl}\right]$ & Rhodium ligand $\left(\mathrm{L}^{1}\right)$ & $52 \% 38 \%$ & $81 \% 12 \%$ & $50 \% 41 \%$ & $4 \% 90 \%$ & $0 \% 98 \%$ & $0 \% 97 \%$ \\
{$\left[\mathrm{Rh}\left(\mathrm{PPh}_{3}\right)_{2}\left(\mathrm{~L}^{2}\right) \mathrm{Cl}\right]$} & Rhodium ligand $\left(\mathrm{L}^{2}\right)$ & $52 \% 38 \%$ & $81 \% 12 \%$ & $52 \% 35 \%$ & $3 \% 90 \%$ & $0 \% 97 \%$ & $0 \% 92 \%$ \\
{$\left[\mathrm{Rh}\left(\mathrm{PPh}_{3}\right)_{2}\left(\mathrm{~L}^{3}\right) \mathrm{Cl}\right]$} & Rhodium ligand $\left(\mathrm{L}^{3}\right)$ & $79 \% 15 \%$ & $32 \% 61 \%$ & $59 \% 31 \%$ & $6 \% 90 \%$ & $10 \% 88 \%$ & $0 \% 98 \%$ \\
\hline
\end{tabular}

using an excitation wavelength of $\sim 320 \mathrm{~nm}$ (Fig. 2, Table 3). Quantum yields $(\phi)$ of these emissions, evaluated with reference to $\left[\mathrm{Ru}(\mathrm{bpy})_{3}\right]\left(\mathrm{ClO}_{4}\right)_{2},{ }^{21}$ indicate that the emission intensity increases appreciably when the azomethine proton in $\left[\mathrm{Rh}\left(\mathrm{PPh}_{3}\right)_{2}\left(\mathrm{~L}^{1}\right) \mathrm{Cl}\right]$ is replaced by an electron-donating methyl group (as in $\left.\left[\mathrm{Rh}\left(\mathrm{PPh}_{3}\right)_{2}\left(\mathrm{~L}^{2}\right) \mathrm{Cl}\right]\right)$. Compared to $\left[\mathrm{Rh}\left(\mathrm{PPh}_{3}\right)_{2}\left(\mathrm{~L}^{1}\right) \mathrm{Cl}\right]$ the emission intensity is also higher in the $\left[\mathrm{Rh}\left(\mathrm{PPh}_{3}\right)_{2}\left(\mathrm{~L}^{3}\right) \mathrm{Cl}\right]$ complex, which is attributable to the higher degree of charge delocalization possible over the naphthyl ring in this complex.

Electrochemical properties of the $\left[\mathrm{Rh}\left(\mathrm{PPh}_{3}\right)_{2}(\mathrm{~L}) \mathrm{Cl}\right]$ complexes have been studied by cyclic voltammetry. Voltammetric data are presented in Table 5 and a selected voltammogram is displayed in Fig. 4. Each complex shows two oxidative responses on the positive side of the SCE and one reductive response on the negative side. All three responses are irreversible in nature. The first oxidative response is assigned to rhodium(III) to rhodium(IV) oxidation. The one-electron nature of this oxidation has been established by comparing its current height $\left(i_{\mathrm{pa}}\right)$ with that of the ferrocene/ferrocenium couple under identical experimental conditions. The second oxidative response is believed to be centered on the thiosemicarbazone

Table 5 Cyclic voltammetric data

\begin{tabular}{lll}
\hline \multirow{2}{*}{ Compound } & \multicolumn{2}{l}{$E / \mathrm{V}$ vs. SCE } \\
\cline { 2 - 3 } & $E_{\mathrm{pa}}$ & $E_{\mathrm{pc}}$ \\
\hline$\left[\mathrm{Rh}\left(\mathrm{PPh}_{3}\right)_{2}\left(\mathrm{~L}^{1}\right) \mathrm{Cl}\right]$ & $0.85,1.13$ & -1.05 \\
{$\left[\mathrm{Rh}\left(\mathrm{PPh}_{3}\right)_{2}\left(\mathrm{~L}^{2}\right) \mathrm{Cl}\right]$} & $0.83,1.40$ & -1.14 \\
{$\left[\mathrm{Rh}\left(\mathrm{PPh}_{3}\right)_{2}\left(\mathrm{~L}^{3}\right) \mathrm{Cl}\right]$} & $0.77,1.23$ & -1.13
\end{tabular}

${ }^{a}$ In $1: 9$ dichloromethane-acetonitrile; supporting electrolyte, TBAP; scan rate $50 \mathrm{mV} \mathrm{s}^{-1}$.

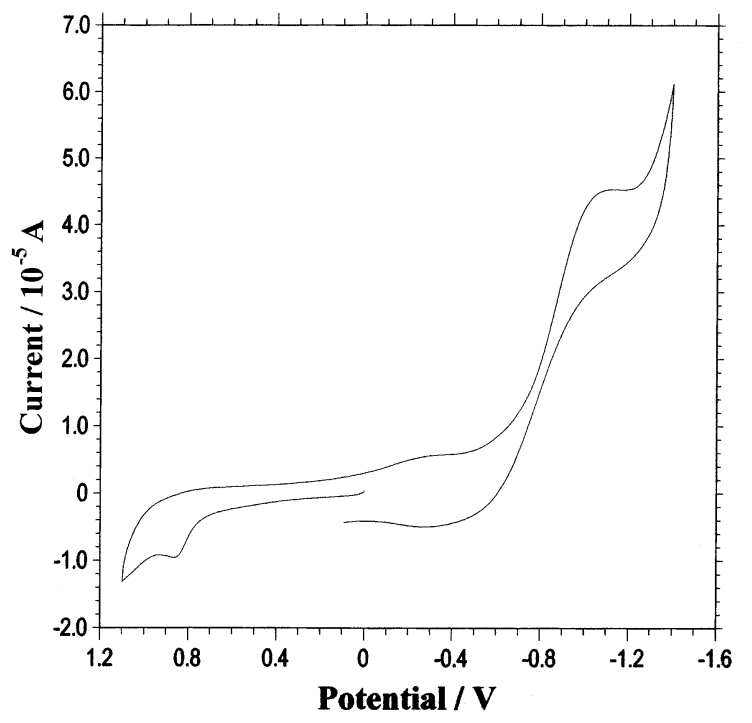

Fig. 4 Cyclic voltammogram of $\left[\mathrm{Rh}\left(\mathrm{PPh}_{3}\right)_{2}\left(\mathrm{~L}^{2}\right) \mathrm{Cl}\right]$ in $1: 9$ dichloromethane-acetonitrile solution (0.1 M TBAP) at a scan rate of $50 \mathrm{mV} \mathrm{s}^{-1}$. ligand. The reductive response is assigned to the rhodium(III) to rhodium(II) reduction. The irreversible nature of the redox responses indicates that while the trivalent state of rhodium is quite comfortable in these complexes, the higher and lower oxidation states are not.

\section{Conclusion}

The present study shows that salicylaldehyde thiosemicarbazone and similar ligands can smoothly bind to a metal ion as tridentate $\mathrm{O}, \mathrm{N}, \mathrm{S}$-donors, provided an adequate number of coordination sites are readily available on the target metal ion. With the knowledge gained from the present study, attempts are now underway to bind these ligands in the $\mathrm{O}, \mathrm{N}, \mathrm{S}$-tridentate fashion to ruthenium and osmium, for which only four-membered N, S-chelates were obtained before.

\section{Acknowledgements}

Financial assistance received from the Council of Scientific and Industrial Research, New Delhi [Grant No. 01(1675)/00/ EMR-II] is gratefully acknowledged. The authors thank Professor S. Lahiri of Department of Organic Chemistry, Indian Association for the Cultivation of Science, Kolkata, for her help and the Bose Institute, Calcutta 700054, for NMR spectral measurements. SD thanks CSIR for her fellowship.

\section{References}

1 (a) M. J. M. Campbell, Coord. Chem. Rev., 1975, 15, 279; (b) S. B. Padhye and G. B. Kaffman, Coord. Chem. Rev., 1985, 63, 127; (c) I. Haiduc and C. Silvestru, Coord. Chem. Rev., 1990, 99, 253; (d) D. X. West, S. B. Padhye and P. B. Sonawane, Struct. Bonding, 1992, 76, 1; (e) D. X. West, A. E. Liberta, S. B. Padhye, R. C. Chikate, P. B. Sonawane, A. S. Kumbhar and R. G. Yerande, Coord, Chem. Rev., 1993, 123, 49.

2 (a) F. A. French and E. Blanz Jr., J. Med. Chem., 1970, 13, 1117; (b) A. C. Sartorellic, K. C. Agrawal, A. S. Tsiftsoglou and A. C. Moore, Adv. Enzyme Regul., 1977, 15, 117; (c) K. C. Agrawal and A. C. Sartorelli, Prog. Med. Chem., 1978, 15, 321; (d) J. P. Scovill, D. L. Klayman and C. F. Franchino, J. Med. Chem., 1982, 25 1261; (e) A. Kraker, S. Krezoski, J. Schneider, D. Mingel and D. H. Petering, J. Biol. Chem., 1985, 260, 13710; $(f)$ A. E. Liberta and D. X. West, Biometals, 1992, 5, 121; $(g)$ D. Kovala-Demertzi, A. Domopoulou, M. A. Demertzis, C. P. Raptopoulou and A. Terzis, Polyhedron, 1994, 13, 1917; (h) A. Papageorgiou, Z. Iakovidou, D. Mourelatos, E. Mioglou, L. Boutis, A. Kotsis, D. Kovala-Demertzi, A. Domopoulou, D. X. West and M. A. Demertzis, Anticancer Res., 1997, 17, 247; (i) M. C. Miller III, C. N. Stineman, J. R. Vance, D. X. West and I. H. Hall, Anticancer Res., 1998, 18, 4131; (j) D. Kovala-Demertzi, J. R. Miller, N. Kourkoumelis, S. K. Hadjikakou and M. A. Demertzis, Polyhedron, 1999, 18, 1005; $(k)$ Z. Iakovidou, A. Papageorgiou, M. A. Demertzis, E. Mioglou, D. Mourelatos, A. Kotsis, P. N Yadav and D. Kovala-Demertzi, Anticancer Drugs, 2001, 12, 65.

3 Y. P. Tion, C. Y. Duan, Z. L. Lu, X. Z. You, H. K. Fun and S. Kandasamy, Polyhedron, 1996, 15, 2263.

4 (a) A. De Bolfo, T. D. Smith, J. F. Boas and J. R. Pilbrow, Aust. J. Chem., 1976, 29, 2583; (b) Z. Lu, C. White, A. L. Rheingold and R. H. Crabtree, Inorg. Chem., 1993, 32, 3991; (c) D. X. West, Y.-H. Yang, T. L. Klein, K. I. Goldberg, A. E. Liberta, J. Valdés-Martínez and R. A. Toscano, Polyhedron, 1995, 14, 1681; (d) D. X. West, Y.-H. Yang, T. L Klein, K. I. Goldberg, 
A. E. Liberta, J. Valdés-Martínez, S. Hernández-Ortega, Polyhedron, 1995, 14, 3051.(e) P. Souza, I. A. Matesanz and V. Fernandez, J. Chem. Soc., Dalton Trans., 1996, 3011; $(f)$ D. Kovala-Demertzi, A. Domopoulou, M. A. Demertzis, J. ValdézMartínez, S. Hernández-Ortega, G. Espinosa-Pérez, D. X. West, M. M. Salberg, G. A. Bain and P. D. Bloom, Polyhedron, 1996, 15, 2587; $(g)$ M. A. Ali, K. K. Dey, M. Nazimuddin, F. E. Smith, R. J. Butcher, J. P. Jasinski and J. M. Jasinski, Polyhedron, 1996, 15, 3331 .

5 (a) D. Kovala-Demertzi, N. Kourkoumelis, M. A. Demertzis, J. R. Miller, C. S. Frampton, J. K. Swearingen and D. X. West, Eur. J. Inorg. Chem., 2000, 727; (b) P. N. Yadav, M. A. Demertzis, D. Kovala-Demertzi, A. Castineiras and D. X. West, Inorg. Chim. Acta, 2002, 332, 204.

6 F. Basuli, S.-M. Peng and S. Bhattacharya, Inorg. Chem., 1997, 36, 5645 .

7 (a) A. Castineiras, E. Bermejo, D. X. West, A. K. EI-Sawaf and J. K. Swearingen, Polyhedron, 1998, 17, 2751; (b) A. Castineiras, M. Gil, E. Bermejo and D. X. West, Z. Naturforsch. B: Chem. Sci., 2000, 55, 863; (c) E. Bermejo, A. Castineiras, L. J. Ackerman, M. D. Owens and D. X. West, Z. Anorg. Allg. Chem., 2001, 627, 1966; (d) C. A. Brown, W. Kaminsky, K. A. Claborn, K. I. Goldberg and D. X. West, J. Braz. Chem. Soc., 2002, 13, 10.

8 I. Pal, F. Basuli, T. C. W. Mak and S. Bhattacharya, Angew. Chem., Int. Ed., 2001, 40, 2923.

9 (a) F. Basuli, M. Ruf, C. G. Pierpont and S. Bhattacharya, Inorg. Chem., 1998, 37, 6113; (b) F. Basuli, S.-M. Peng and S. Bhattacharya, Inorg. Chem., 2000, 39, 1120.

10 F. A. Cotton and G. Wilkinson, Advanced Inorganic Chemistry, Wiley Eastern, New Delhi, 1985, p. 788.
11 (a) S. Dutta, S.-M. Peng and S. Bhattacharya, Inorg. Chem., 2000, 39, 2231; (b) S. Dutta, S.-M. Peng and S. Bhattacharya, J. Chem. Soc., Dalton Trans., 2000, 4623; (c) A. Das, F. Basuli, S.-M. Peng and S. Bhattacharya, Inorg. Chem., 2002, 41, 440.

12 J. A. Osborn and G. Wilkinson, Inorg. Synth., 1967, 10, 67.

13 (a) D. T. Sawyer and J. L. Roberts, Jr., Experimental Electrochemistry for Chemists, Wiley, New York, 1974, pp. 167-215; (b) M. Walter and L. Ramaley, Anal. Chem., 1973, 45, 165.

14 G. M. Sheldrick, SHELXS-97 and SHELXL-97, Fortran Programs for Crystal Structure Solution and Refinement, University of Göttingen, Germany, 1997.

15 (a) J. Valdés-Martínez, R. A. Toscano and A. Zentella-Dehesa, Polyhedron, 1996, 15, 427; (b) Y. Kaneko, N. Suzuki, A. Nishiyama, T. Suzuki and K. Isobe, Organometallics, 1998, 17, 4875 .

16 M. Soriano-García, J. Valdés-Martínez and R. A. Toscano, Acta. Crystallogr., Sect. C, 1988, 44, 1247.

17 (a) M. Soriano-García, R. A. Toscano, J. Valdés-Martínez and J. M. Fernández-G, Acta Crystallogr., Sect. C, 1985, 41, 498; (b) M. Soriano-García, J. Valdés-Martínez, R. A. Toscano and J. Gómez-Lara, Acta Crystallogr., Sect. C, 1985, 41, 500; (c) K. Hashizume, Y. Mizobe and M. Hidai, Organometallics, 1996, 15, 3303.

18 B. R. James and L. D. Markham, Inorg. Chem., 1974, 13, 97.

19 (a) C. Mealli and D. M. Proserpio, CACAO v. 4.0, Firenze, Italy, 1994; (b) C. Mealli and D. M. Proserpio, J. Chem. Educ., 1990, 67 399.

20 The HOMO-1 in $\left[\mathrm{Rh}\left(\mathrm{PPh}_{3}\right)_{2}\left(\mathrm{~L}^{3}\right) \mathrm{Cl}\right]$ has slightly less metal character.

21 R. Alsfasser and R. V. Eldik, Inorg. Chem., 1996, 35, 628. 